Deiksis: Jurnal Pendidikan Bahasa dan Sastra Indonesia, 7 (1) Januari 2020

DOI: $10.33603 /$ deiksis.v7i1.2578

(p-ISSN 2355-6633, e-ISSN 2548-5490)

\title{
Sikap Berbahasa Masyarakat Kota Cirebon pada Bahasa Cirebon
}

\author{
Aveny Septi Astriani1), Handayani Nila Praja ${ }^{2)}$ \\ Universitas Siliwangi ${ }^{1)}$, Universitas 17 Aguatus 1945 Cirebon $^{2)}$ \\ aveny.septi@unsil.ac.id
}

\begin{abstract}
Abstrak. Penelitian tentang sikap berbahasa pada bahasa Cirebon sangat penting untuk dilakukan. Hal ini karena bahasa Cirebon yang biasa disebut basa Cerbon telah menjadi bahasa yang mandiri berdasarkan Peraturan Daerah Provinsi Jawa Barat Nomor 5 Tahun 2003. Secara geografis wilayah Cirebon berbatasan dengan dua provinsi, yaitu Jawa Barat dan Jawa Tengah. Wilayah Cirebon terdiri atas Kota dan Kabupaten Cirebon. Pada penelitian ini, peneliti memilih Kota Cirebon sebagai wilayah yang akan diteliti karena Kota Cirebon merupakan kota yang terdiri atas masyarakat yang multilingual, multietnis, dan multikultural. Teori yang melandasi penelitian ini adalah teori sosiolinguistik, bilingualisme, dan sikap bahasa. Penelitian ini merupakan penelitian kuantitatif deskriptif dengan menggunakan metode survey dan membagikan kuesioner ke seratus narasumber yang dibagi secara acak di lima kecamatan di Kota Cirebon. Berdasarkan tujuh ranah yang diteliti, dapat disimpulkan bahwa penggunaan bahasa masyarakat Kota Cirebon di 2 ranah (keluarga dan karib) menggunakan bahasa percampuran antara bahasa Cirebon dan Indonesia (skala 3), 1 ranah (tetangga) lebih sering menggunakan bahasa Indonesia daripada bahasa Cirebon (skala 4), 3 ranah (pendidikan, umum, dan agama) selalu menggunakan bahasa Indonesia (skala 5). Oleh karena itu, hasil dari penelitian ini adalah sikap bahasa masyarakat Kota Cirebon pada bahasa Cirebon mengalami kemunduran, tidak positif tetapi berpengaruh ke negatif.
\end{abstract}

Kata kunci : sikap bahasa, bahasa Cirebon, sosiolinguistik

\section{Pendahuluan}

Penelitian tentang sikap berbahasa pada bahasa Cirebon sangat penting untuk dilakukan. Hal ini karena bahasa Cirebon yang biasa disebut basa Cerbon telah menjadi bahasa yang mandiri berdasarkan Peraturan Daerah Provinsi Jawa Barat Nomor 5 Tahun 2003. Pada Kongres basa Cerbon II, Kartika, M.Hum dalam Suplemen Pikiran Rakyat (2013) mengungkapkan bahwa "Secara politis dan linguistis, bahasa Cirebon sudah memiliki 'kekuatan' untuk tumbuh dan berkembang secara sempurna sebagai bahasa yang mandiri'. Lebih lanjut Kartika menjelaskan bahwa "Perbedaan yang ditujukkan bahasa Jawa Yogyakarta dan bahasa Jawa Cerbon masa kini sudah sangat banyak. Secara leksikal, perbedaan itu tampak mencolok dengan adanya perbedaan yang digunakan di Yogyakarta dan Cirebon. Dengan demikian, penetapan bahasa Jawa Cerbon sebagai bahasa yang mandiri mendapatkan legitimasi linguistis, sehingga bahasa Jawa Cerbon kini ditetapkan sebagai bahasa Cerbon”.

Walaupun bahasa Cirebon tergolong masih muda secara de jure, bahasa Cirebon telah digunakan oleh masyarakat Cirebon secara de facto jauh sebelum tahun 2003, namun pada saat itu masih disebut sebagai bahasa Jawa dialek Cirebon atau bahasa Jawa dialek Sunda. Fenomena tersebut terjadi karena secara geografis wilayah Cirebon berbatasan dengan dua provinsi, yaitu Jawa Barat dan Jawa Tengah. Wilayah Cirebon terdiri atas Kota dan Kabupaten 
Deiksis: Jurnal Pendidikan Bahasa dan Sastra Indonesia, 7 (1) Januari 2020

DOI: $10.33603 /$ deiksis.v7i1.2578

(p-ISSN 2355-6633, e-ISSN 2548-5490)

Cirebon. Pada penelitian ini, peneliti memilih Kota Cirebon sebagai wilayah yang akan diteliti karena Kota Cirebon merupakan kota yang terdiri atas masyarakat yang multilingual, multietnis, dan multikultural. Multilingual artinya penduduk Kota Cirebon mempunyai keragaman bahasa yaitu bahasa Sunda, bahasa Jawa, bahasa Cirebon, bahasa Indonesia, dan bahasa asing. Keragaman tersebut karena Kota Cirebon merupakan pusat ekonomi di wilayah Ciayumajakuning, sehingga banyak imigran yang bekerja ke Kota Cirebon, mempunyai rumah, dan menetap di Kota Cirebon. Multietnis artinya penduduk Kota Cirebon terdiri atas berbagai suku seperti suku Sunda, Jawa, Tionghoa, dan Arab, sehingga gesekan perbedaan bahasa pasti akan terjadi. Sedangkan multikultural artinya Kota Cirebon mempunyai banyak budaya yang berasal dari akulturasi berbagai budaya yang satu dengan budaya yang lain.

Selain itu, IPM (Indeks Pembangunan Manusia) Kota Cirebon lebih tinggi dari Kab. Cirebon. Berdasarkan data BPS, IPM Kota Cirebon tahun 2018 adalah 74,35 sedangkan Kab. Cirebon 68,05. Adanya Indeks Pembangunan Masyarakat bertujuan untuk mengetahui bagaimana penduduk dapat mengakses hasil pembangunan dalam memperoleh pendapatan, kesehatan, pendidikan, dan sebagainya. Hal ini mengindikasikan bahwa Kota Cirebon merupakan Kota dengan penduduk yang memiliki tingkat hetererogen yang tinggi dengan latar belakang pendidikan, pekerjaan, dan bahasa yang yang heterogen dibandingkan wilayah kabupaten. Sehingga kontak bahasa yang terjadi pun akan semakin banyak antara bahasa yang satu dengan bahasa yang lain.

Banyaknya faktor yang menyebabkan kontak bahasa tersebut bisa menyebabkan kurangnya loyalitas masyarakat lokal terhadap bahasa Cirebon, sehingga bahasa Cirebon sebagai bahasa daerah perlu dilestarikan dan dibudayakan agar tidak terlupakan oleh generasi penerus. Bahasa daerah merupakan warisan leluhur yang harus dijaga dan dilestarikan dari ancaman kepunahan. Dalby (Ruddyanto, 2009) memaparkan bahwa kepunahan bahasa berarti hilangnya khazanah ungkapan yang mencerminkan cara pandang penuturnya terhadap dunia. Tiga faktor yang menjadi penyebab punahnya suatu bahasa adalah 1) penutur bahasa memilih tidak membelajarkan bahasa ibu kepada anak-anaknya dan memilih tidak menggunakannya secara aktif dalam ranah pertuturan di rumah, 2) tekanan bahasa mayoritas dalam suatu kawasan masyarakat multilingual, dan 3) penutur memilih tidak menggunakan bahasa ibu dan menggunakan sebuah bahasa lain (Ibrahim, 2011).

Berdasarkan latar belakang yang telah dikemukakan, maka peneliti akan mendeskripsikan sikap berbahasa masyarakat Kota Cirebon terhadap bahasa Cirebon. Apakah masih positif atau cenderung negatif, sehingga penelitian ini layak untuk dilanjutkan.

Teori yang mendasari penelitian ini adalah teori tentang sosiolinguistik, bilingualisme, serta sikap bahasa. Sosiolinguistik adalah kajian tetang ciri khas variasi bahasa, fungsi variasi bahasa, dan pemakai bahasa karena ketiga unsur ini selalu berinteraksi, berubah, dan saling mengubah satu sama lain dalam satu masyarakat tutur (Fishman, 1972). Apabaila dua bahasa atau lebih digunakan secara bergantian oleh penutur yang sama, maka dapat dikatakan bahwa bahasabahasa tersebut dalam keadaan saling kontak (Suwito, 1985). Lebih lanjut Suwito menjelaskan bahwa kontak bahasa meliputi segala peristiwa persentuhan beberapa bahasa yang berakibat adanya kemungkinan pergantian pemakaian bahasa oleh penutur dalam konteks sosialnya. Peristiwa semacam itu antara lain nampak dalam wujud kedwibahasaan dan diglosia. 
Deiksis: Jurnal Pendidikan Bahasa dan Sastra Indonesia, 7 (1) Januari 2020

DOI: $10.33603 /$ deiksis.v7i1.2578

(p-ISSN 2355-6633, e-ISSN 2548-5490)

Kedwibahasaan menurut Weinreich (1968) yaitu peristiwa pemakaian dua bahasa (atau lebih) secara bergantian oleh seorang penutur. Dalam masyarakat yang multilingal akan terdapat berbagai macam pola kedwibahasaan. Nababan (1993) membagi pola tersebut menjadi beberapa unsur yaitu 1) bahasa yang dipakai, 2) bidang (domain) kebahasaan, dan 3) teman berbahasa. Jadi pola kedwibahasaan itu menjawab pertanyaan : bahasa mana yang dipakai orang, untuk bidang kebahasaan apa, dan kepada siapa? Sikap dalam KBBI (versi 5 daring) adalah perbuatan dan sebagainya yang berdasarkan pada pendirian, keyakinan; perilaku; gerakgerik. Lambert (1976) menyatakan bahwa sikap terdiri atas tiga komponen, yaitu komponen kognitif, afektif, dan konatif. Triandis (dalam Wagiati, 2017) melengkapi pernyataan Lambert bahwa sikap ditentukan oleh perbuatan. Sikap bertautan dengan pikiran, perasaan, dan keinginan seseorang mengenai suatu keadaan yang ditentukan oleh norma sosial yang berlaku. Sekaitan dengan sikap, Anderson (1974) membagi sikap dalam dua jenis, yaitu sikap kebahasaan dan nonkebahasaan (sikap politik, sosial, estetis, dan sikap keagamaan). Sikap bahasa yang ditunjukkan oleh seseorang mempunyai ciri-ciri tertentu. Menurut Dittmar (1976) pengertian sikap bahasa ditandai oleh ciri-ciri sebagai berikut: (1) Pemilihan bahasa dalam masyarakat multilingual, (2) Distribusi perbendaharaan bahasa, (3) Perbedaan dialektikal dan problem yang timbul sebagai akibat adanya interaksi antarindividu.

Apabila di dalam suatu masyarakat dikenal lebih dari satu bahasa, maka pemilihan bahasa manakah yang akan digunakan sebagai alat komunikasi umum di dalam masyarakat itu menunjukkan sikap masyarakat terhadap bahasa tersebut (Suwito, 1985). Sikap bahasa suatu masyarakat dibagi menjadi sikap positif dan negatif. Ciri-ciri sikap bahasa positif yaitu 1) kesetiaan bahasa (language loyalty) yang mendorong masyarakat suatu bahasa mempertahankan bahasanya, dan apabila perlu mencegah adanya pengaruh bahasa lain, 2) kebanggaan bahasa (language pride) yang mendorong orang mengembangkan bahasanya dan menggunakannya sebagai lambang identitas dan kesatuan masyarakat, 3) kesadaran adanya norma bahasa (awareness of the norm) yang mendorong orang mengembangkan bahasanya dan menggunakan bahasanya dengan cermat dan santun dan merupakan faktor yang sangat besar pengaruhnya terhadap perbuatan yaitu kegiatan menggunakan bahasa (language use) (Garvin dan Mathiot dalam Chaer dan Agustina, 2004). Sebaliknya, jika ketiga ciri tersebut sudah menghilang atau melemah dari diri seseorang atau sekelompok orang anggota masyarakat tutur maka berarti sikap negatif melanda sekelompok orang itu.

\section{Metode}

Penelitian ini menggunakan jenis penelitian kuantitatif deskriptif. Data yang penulis kaji adalah hasil kuesioner dan hasil wawancara yang dilakukan kepada masyarakat Kota Cirebon. Pengambilan data dilakukan secara purposif sampling kepada masyarakat Kota Cirebon dengan syarat warga Kota Cirebon asli (menunjukkan KTP) berusia 10-60 tahun. Pengambilan sampel dilakukan di lima kecamatan yang ada di Kota Cirebon yaitu Harjamukti, Kejaksan, Kesambi, Lemahwungkuk, dan Pekalipan dengan menggunakan rumus slovin dengan tingkat presisi $10 \%$. Jumlah sampel yang diperoleh setelah menggunakan rumus slovin berjumlah 100 responden. Jumlah tersebut dibagi lagi berdasarkan umur yaitu remaja 10-20 tahun dengan jumlah 30 responden, dewasa 21-40 tahun dengan jumlah 50 responden, berumur 41-60 tahun 
Deiksis: Jurnal Pendidikan Bahasa dan Sastra Indonesia, 7 (1) Januari 2020

DOI: $10.33603 /$ deiksis.v7i1.2578

(p-ISSN 2355-6633, e-ISSN 2548-5490) dengan jumlah 20 responden. Agar persebaran data lebih maksimal, peneliti membagi rata 100 responden ke lima kecamatan. Jadi, masing-masing kecamatan disebar 20 kuesioner dengan rincian usia 10-20 tahun 6 orang, 21-40 tahun 10 orang, dan 41-60 tahun 4 orang. Pembagian umur tersebut mengacu pada perbandingan umur jumlah penduduk masyarakat Kota Cirebon.

Metode penyediaan data yang peneliti gunakan adalah metode survey dengan teknik membagikan kuesioner kepada responden. Peneliti membuat daftar pertanyaan yang berkaitan dengan data kebahasaan diri dan keluarga responden. Selain itu, di dalam kuesioner juga berisi daftar pertanyaan yang memancing pengakuan responden tentang pemakaian dan pilihan bahasa yang digunakan. Dalam kuesioner tersebut disediakan dua pilihan bahasa untuk dipilih yaitu bahasa Cirebon (BC) dan bahasa Indonesia (BI). Responden diminta untuk mengisi kuesioner yang telah disediakan oleh peneliti berupa daftar tanya mengenai tujuh ranah komunikasi yaitu ranah keluarga, tetangga, karib, pendidikan, pemerintahan, umum, dan agama. Penilaian kuesioner menggunakan skala Likert sebagai berikut :

$1=$ Selalu (hampir selalu) BC

$2=$ Lebih sering $\mathrm{BC}$ daripada $\mathrm{BI}$

$3=$ Sama seringnya $\mathrm{BC}$ dan $\mathrm{BI}$

4= Lebih sering BI daripada BC

$5=$ Selalu (hampir selalu) BI

Kuesioner kemudian dibagikan secara acak ke lima kecamatan di Kota Cirebon. Selain kuesioner, peneliti juga melakukan wawancara kepada responden. Wawancara tersebut bertujuan menggali informasi tentang penggunaan bahasa masyarakat Kota Cirebon secara lisan dan mencatatnya dalam lembar kertas. Data yang telah diolah kemudian disajikan dalam bentuk tabel, grafik, dan dianalisis menggunakan kalimat deskriptif

\section{Pembahasan}

Data yang telah diperoleh dan dianalisis diklasifikasikan menjadi beberapa ranah, yaitu ranah keluarga, tetangga, karib, pendidikan, pemerintahan, umum, dan ranah agama.

1. Ranah Keluarga

Hasil sikap bahasa masyarakat Kota Cirebon terhadap bahasa Cirebon di ranah keluarga ditampilkan melalui tabel berikut.

Tabel 1.1 Hasil Sikap Bahasa Ranah Keluarga

\begin{tabular}{|c|c|c|c|c|c|c|c|c|c|c|c|c|}
\hline \multirow{3}{*}{ Ranah } & \multirow{3}{*}{ Usia } & \multirow{3}{*}{$\begin{array}{l}\text { Jml } \\
\text { res- } \\
\text { pon- } \\
\text { den }\end{array}$} & \multicolumn{10}{|c|}{ Jumlah Perolehan Sikap Bahasa dalam Jumlah dan Persentase } \\
\hline & & & \multicolumn{2}{|c|}{$\begin{array}{c}\text { (1) } \\
\text { selalu BC }\end{array}$} & \multicolumn{2}{|c|}{$\begin{array}{c}\text { (2) } \\
\text { lebih sering } \\
\text { BC drpd BI } \\
\end{array}$} & \multicolumn{2}{|c|}{$\begin{array}{c}(3) \\
\text { sama sering BC } \\
\text { dan BI }\end{array}$} & \multicolumn{2}{|c|}{\begin{tabular}{c}
\multicolumn{1}{c}{$(4)$} \\
lebih sering \\
BI drpd BC \\
\end{tabular}} & \multicolumn{2}{|c|}{$\begin{array}{c}\text { (5) } \\
\text { selalu BI }\end{array}$} \\
\hline & & & $\begin{array}{c}\text { Jml } \\
\text { jwban }\end{array}$ & $\begin{array}{c}\text { Per- } \\
\text { sen }\end{array}$ & $\begin{array}{c}\text { Jml } \\
\text { jwba } \\
\mathbf{n}\end{array}$ & $\begin{array}{c}\text { Per- } \\
\text { sen }\end{array}$ & $\begin{array}{c}\text { Jml } \\
\text { jwban }\end{array}$ & $\begin{array}{c}\text { Perse } \\
\text { n }\end{array}$ & $\begin{array}{c}\text { Jml } \\
\text { jwba } \\
\text { n }\end{array}$ & $\begin{array}{c}\text { Per- } \\
\text { sen }\end{array}$ & $\underset{\text { jwban }}{\text { Jml }}$ & $\begin{array}{l}\text { Per- } \\
\text { sen }\end{array}$ \\
\hline \multirow{4}{*}{$\begin{array}{l}\text { Keluarga } \\
\text { (25 } \\
\text { pertanyaan) }\end{array}$} & $10-20$ th & 30 & 82 & 10.93 & 19 & 2.53 & 74 & 9.87 & 146 & 19.47 & 200 & 26.67 \\
\hline & $21-40$ th & 50 & 229 & 18.32 & 132 & 10.56 & 449 & 35.92 & 318 & 25.44 & 201 & 16.08 \\
\hline & $41-60$ th & 20 & 90 & 18.00 & 39 & 7.8 & 186 & 37.2 & 131 & 26.2 & 87 & 17.4 \\
\hline & jml & 100 & 401 & 16.04 & 190 & 7.6 & 709 & 28.4 & 595 & 23.8 & 488 & 19.52 \\
\hline
\end{tabular}


Deiksis: Jurnal Pendidikan Bahasa dan Sastra Indonesia, 7 (1) Januari 2020

DOI: $10.33603 /$ deiksis.v7i1.2578

(p-ISSN 2355-6633, e-ISSN 2548-5490)

Pada tabel 1.1, ranah keluarga diejawantahkan dalam 25 pertanyaan yang dijawab oleh 100 responden dengan rincian responden yang berusia 10-20 tahun terdiri atas 30 responden, 21-40 tahun 50 responden, dan 41-60 tahun berjumlah 20 responden. Kolom jml jwbn (jumlah jawaban) merujuk pada banyaknya responden yang memilih nomor (1) selalu menggunakan BC (Bahasa Cirebon), (2) lebih sering BC daripada BI, sampai nomor (5) selalu BI (Bahasa Indonesia).

Sikap bahasa yang dituangkan dalam tabel 5.1 dikelompokkan dalam tiga generasi, yaitu generasi usia 10-20 tahun, usia 21-40 tahun, dan usia 41-60 tahun dengan rincian sebagai berikut.

Sikap bahasa terbanyak pada generasi usia 10-20 tahun adalah di skala (5) selalu menggunakan bahasa Indonesia dengan perolehan 200 dari 750 jawaban $(26,67 \%)$. Berikutnya adalah skala (4) lebih sering menggunakan bahasa Indonesia daripada bahasa Cirebon dengan jumlah 146 dari 750 jawaban (19,47\%). Skala selanjutnya yaitu skala (1) Selalu menggunakan bahasa Cirebon dengan jumlah 82 dari 750 jawaban (10,93\%), skala (3) sama seringnya panggunaan bahasa Cirebon dan bahasa Indonesia dengan jumlah 74 dari 750 jawaban $(9,87 \%)$, dan skala terakhir yang paling sedikit penggunanya yaitu skala (2) lebih sering bahasa Cirebon daripada bahasa Indonesia dengan jumlah 19 dari 750 jawaban $(2,53 \%)$.

Jumlah sikap bahasa yang paling banyak dilakukan pada generasi usia 21-40 tahun terdapat pada skala (3) juga, yaitu sama seringnya penggunaan bahasa Cirebon dan bahasa Indonesia, sebanyak 449 dari 1250 jawaban (35,92\%). Pemilihan bahasa selanjutnya adalah adalah skala (4) lebih sering menggunakan bahasa Indonesia daripada bahasa Cirebon dengan perolehan jumlah 318 dari 1250 jawaban (25.44\%). Setelah itu skala (1) selalu menggunakan bahasa Cirebon dengan jumlah 229 dari 1250 jawaban (18,32\%), dan skala (5) selalu menggunakan bahasa Indonesia dengan jumlah 201 dari 1250 jawaban (16,08\%). Sikap bahasa yang paling sedikit dipilih oleh generasi usia 21-40 yaitu skala (2) lebih sering menggunakan bahasa Cirebon daripada bahasa Indonesia dengan jumlah 132 dari 1250 pertanyaan (10,56\%).

Pada generasi usia 41-60 tahun, sikap bahasa mereka secara berurutan yaitu skala (3) sama seringnya menggunakan bahasa Cirebon dan bahasa Indonesia dengan jumlah 186 dari 500 jawaban $(37,20 \%)$, skala (4) lebih sering menggunakan bahasa Indonesia daripada bahasa Cirebon dengan jumlah 131 dari 500 jawaban (26,2\%), skala (1) selalu menggunakan bahasa Cirebon dengan jumlah 90 dari 500 jawaban (18\%), skala (5) selalu menggunakan bahasa Indonesia dengan jumlah 87 dari 500 jawaban $(17,4 \%)$, dan yang terakhir skala (2) lebih sering menggunakan bahasa Cirebon daripada bahasa Indonesia dengan jumlah 39 dari 500 jawaban $(7,8 \%)$.

Hasil seluruh sikap bahasa masyarakat Kota Cirebon terhadap bahasa Cirebon yang diperoleh pada ranah keluarga yaitu terdapat 709 dari 2500 jawaban (28.4\%) pada skala (3) sama seringnya antara menggunakan bahasa Cirebon dan bahasa Indonesia, selanjutnya skala (4) lebih sering menggunakan bahasa Indonesia daripada bahasa Cirebon dengan jumlah 595 dari 2500 jawaban (23.8\%). Sikap bahasa berikutnya terdapat pada skala (5) selalu menggunakan bahasa Indonesia dengan jumlah 488 dari 2500 (19,52\%). Urutan keempat pada skala (1) selalu menggunakan bahasa Cirebon dengan jumlah 401 drai 2500 jawaban $(16,04 \%)$, 
Deiksis: Jurnal Pendidikan Bahasa dan Sastra Indonesia, 7 (1) Januari 2020

DOI: $10.33603 /$ deiksis.v7i1.2578

(p-ISSN 2355-6633, e-ISSN 2548-5490)

dan skala terakhir adalah skala (2) lebih sering menggunakan bahasa Cirebon daripada bahasa Indonesia dengan jumlah 190 dari 2500 jawaban (7,6\%).

2. Ranah Tetangga

Ranah tetangga merupakan ranah peristiwa tutur yang terjadi di sekitar rumah responden. Berikut ini adalah tabel hasil sikap bahasa masyarakat Kota Cirebon terhadap bahasa Cirebon pada ranah tetangga.

Tabel 2.1 Hasil Sikap Bahasa Ranah Tetangga

\begin{tabular}{|c|c|c|c|c|c|c|c|c|c|c|c|c|}
\hline \multirow{3}{*}{ Ranah } & \multirow{3}{*}{ Usia } & \multirow{3}{*}{$\begin{array}{l}\text { Jml } \\
\text { res- } \\
\text { pon- } \\
\text { den }\end{array}$} & \multicolumn{10}{|c|}{ Jumlah Perolehan Sikap Bahasa Dalam Jumlah Dan Persentase } \\
\hline & & & \multicolumn{2}{|c|}{$\begin{array}{c}(1) \\
\text { selalu BC }\end{array}$} & \multicolumn{2}{|c|}{$\begin{array}{c}\text { (2) } \\
\text { lebih sering } \\
\text { BC drpd BI }\end{array}$} & \multicolumn{2}{|c|}{$\begin{array}{c}(3) \\
\text { sama sering } \\
\text { BC dan BI }\end{array}$} & \multicolumn{2}{|c|}{$\begin{array}{c}(4) \\
\text { lebih sering BI } \\
\text { drpd BC }\end{array}$} & \multicolumn{2}{|c|}{$\begin{array}{c}\text { (5) } \\
\text { selalu BI }\end{array}$} \\
\hline & & & $\begin{array}{c}\text { Jml } \\
\text { jwban }\end{array}$ & $\begin{array}{c}\text { Per- } \\
\text { sen }\end{array}$ & $\begin{array}{c}\text { Jml } \\
\text { jwba } \\
\mathbf{n} \\
\end{array}$ & $\begin{array}{c}\text { Per- } \\
\text { sen }\end{array}$ & $\begin{array}{c}\text { Jml } \\
\text { jwba } \\
\text { n } \\
\end{array}$ & $\begin{array}{c}\text { Perse } \\
\mathbf{n} \\
\end{array}$ & $\begin{array}{c}\text { Jml } \\
\text { jwban }\end{array}$ & $\begin{array}{c}\text { Per- } \\
\text { sen }\end{array}$ & $\begin{array}{c}\text { Jml } \\
\text { jwban }\end{array}$ & $\begin{array}{r}\text { Per- } \\
\text { sen }\end{array}$ \\
\hline \multirow{4}{*}{$\begin{array}{l}\text { Tetangga } \\
(15 \\
\text { pertanyaan })\end{array}$} & $10-20$ th & 30 & 29 & 6.44 & 21 & 4.67 & 50 & 11.11 & 116 & 25.78 & 137 & 30.44 \\
\hline & $21-40$ th & 50 & 92 & 12.27 & 66 & 8.8 & 196 & 26.13 & 234 & 31.20 & 136 & 18.13 \\
\hline & $41-60$ th & 20 & 58 & 19.33 & 36 & 12 & 84 & 28 & 62 & 20.67 & 54 & 18 \\
\hline & jml & 100 & 179 & 11.933 & 123 & 8.2 & 330 & 22 & 412 & 27.47 & 327 & 21.8 \\
\hline
\end{tabular}

Pada tabel 2.1, hasil sikap bahasa masyarakat Kota Cirebon pada bahasa Cirebon yang terjadi di ranah tetangga adalah sebagai berikut.

Sikap bahasa yang ditunjukkan generasi usia 10-20 tahun secara berturut-turut adalah skala (5) selalu menggunakan bahasa Indonesia dengan jumlah 137 dari 450 jawaban $(30,4 \%)$, skala (4) lebih sering menggunakan bahasa Indonesia daripada bahasa Cirebon dengan jumlah 116 dari 450 jawaban $(25,78 \%$ ), skala (3) sama seringnya menggunakan bahasa Cirebon dan bahasa Indonesia dengan jumlah 50 dari 450 jawaban (11,11\%), skala (1) selalu menggunakan bahasa Cirebon daripada bahasa Indoensia dengan jumlah 29 dari 450 jawaban (6,44\%), dan yang paling kecil jumlahnya adalah skala (2) yaitu lebih sering menggunakan bahasa Cirebon daripada bahasa Indonesia dengan jumlah 21 dari 450 jawaban $(4,67 \%)$.

Berbeda sedikit dengan generasi usia sebelumnya. Generasi usia 21-40 tahun mempunyai sikap bahasa paling banyak di skala (4) lebih sering menggunakan bahasa Indonesia daripada bahasa Cirebon dengan jumlah 234 dari 750 jawaban (31,20\%), selanjutnya di skala (3) yaitu sama seringnya menggunakan bahasa Cirebon dan bahasa Indonesia dengan jumlah 196 dari 750 jawaban (26,13\%), skala berikutnya adalah skala (5) selalu menggunakan bahasa Indonesia daripada bahasa Cirebon dengan jumlah 136 dari 750 (18,13\%), dan skala (1) selalu menggunakan bahasa Cirebon daripada bahasa Indonesia dengan jumlah 92 dari 750 (12,27\%), dan skala terakhir yaitu skala (2) lebih sering menggunakan bahasa Cirebon daripada bahasa Indonesia dengan jumlah 66 dari 750 jawaban $(8,8 \%)$.

Pada generasi usia 41-60 tahun, sikap bahasa yang ditunjukkan paling dominan adalah di skala (3) sama seringnya menggunakan bahasa Cirebon dan bahasa Indonesia dengan jumlah 84 dari 300 jawaban (28\%), selanjutnya adalah skala (4) lebih banyak menggunakan bahasa Indonesia daripada bahasa Cirebon dengan jumlah 62 dari 300 jawaban $(20,67 \%)$. Berikutnya 
Deiksis: Jurnal Pendidikan Bahasa dan Sastra Indonesia, 7 (1) Januari 2020

DOI: $10.33603 /$ deiksis.v7i1.2578

(p-ISSN 2355-6633, e-ISSN 2548-5490) adalah skala (1) selalu menggunakan bahasa Cirebon, yaitu dengan jumlah 58 dari 300 jawaban $(19,33 \%)$, skala berikutnya adalah skala. Urutan keempat adalah skala (18\%) selalu menggunakan bahasa Indonesia dengan jumlah 54 dari 300 jawaban (18\%), dan urutan paling sedikit yaitu skala (2) lebih sering menggunakan bahasa Cirebon daripada bahasa Indonesia dengan jumlah 36 dari 300 jawaban (12\%).

Berdasarkan jumlah tiga generasi, sikap bahasa masyarakat Kota Cirebon terhadap bahasa Cirebon pada ranah tetangga secara berurutan adalah skala (4) lebih sering menggunakan bahasa Indonesia daripada bahasa Cirebon dengan jumlah 412 (27.47\%), skala (5) selalu menggunakan bahasa Indonesia dengan jumlah 327 (21.8\%), di skala (3) yaitu sama seringnya menggunakan bahasa Cirebon dan bahasa Indonesia dengan jumlah 330 (22\%), skala (1) selalu menggunakan bahaa Cirebon dengan jumlah 179 (11.93\%) dan skala terakhir adalah skala (2) lebih sering menggunakan bahasa Cirebon daripada bahasa Indonesia dengan jumlah $123(8.2 \%)$

\section{Ranah Karib}

Sikap bahasa masyarakat Kota Cirebon terhadap bahasa Cirebon pada ranah karib ditunjukkan pada tabel di bawah ini.

Tabel 3.1 Hasil Sikap Bahasa Ranah Karib

\begin{tabular}{|c|c|c|c|c|c|c|c|c|c|c|c|c|}
\hline \multirow{3}{*}{ Ranah } & \multirow{3}{*}{ Usia } & \multirow{3}{*}{$\begin{array}{c}\text { Jml } \\
\text { res- } \\
\text { pon- } \\
\text { den }\end{array}$} & \multicolumn{10}{|c|}{ Jumlah Perolehan Sikap Bahasa dalam Jumlah dan Persentase } \\
\hline & & & \multicolumn{2}{|c|}{$\begin{array}{c}(1) \\
\text { selalu BC }\end{array}$} & \multicolumn{2}{|c|}{$\begin{array}{c}\text { (2) } \\
\text { lebih sering } \\
\text { BC drpd BI }\end{array}$} & \multicolumn{2}{|c|}{$\begin{array}{c}(3) \\
\text { sama sering } \\
\text { BC dan BI }\end{array}$} & \multicolumn{2}{|c|}{$\begin{array}{c}(4) \\
\text { lebih sering BI } \\
\text { drpd BC }\end{array}$} & \multicolumn{2}{|c|}{$\begin{array}{c}\text { (5) } \\
\text { selalu BI }\end{array}$} \\
\hline & & & $\begin{array}{c}\text { Jml } \\
\text { jwban }\end{array}$ & $\begin{array}{c}\text { Per- } \\
\text { sen }\end{array}$ & $\begin{array}{c}\text { Jml } \\
\text { jwba } \\
\text { n }\end{array}$ & $\begin{array}{l}\text { Per- } \\
\text { sen }\end{array}$ & $\underset{\text { jwban }}{\text { Jml }}$ & $\begin{array}{c}\text { Perse } \\
\mathbf{n}\end{array}$ & $\begin{array}{c}\text { Jml } \\
\text { jwba } \\
\mathrm{n}\end{array}$ & $\begin{array}{c}\text { Per- } \\
\text { sen }\end{array}$ & $\underset{\text { jwban }}{\text { Jml }}$ & $\begin{array}{c}\text { Per- } \\
\text { sen }\end{array}$ \\
\hline \multirow{4}{*}{$\begin{array}{l}\text { Karib } \\
(10 \\
\text { pertanyaan) }\end{array}$} & $10-20$ th & 30 & 20 & 6.67 & 21 & 7 & 58 & 19.33 & 97 & 32.33 & 97 & 32.33 \\
\hline & $21-40$ th & 50 & 79 & 15.80 & 66 & 13.20 & 197 & 39.40 & 99 & 19.80 & 58 & 11.60 \\
\hline & $41-60$ th & 20 & 47 & 23.50 & 28 & 14 & 63 & 31.50 & 28 & 14.00 & 35 & 17.50 \\
\hline & jml & 100 & 146 & 14.6 & 115 & 11.5 & 318 & 31.8 & 224 & 22.4 & 190 & 19 \\
\hline
\end{tabular}

Berdasarkan tabel 3.1, hasil sikap bahasa masyarakat Kota Cirebon pada bahasa Cirebon di ranah karib terdiri atas tiga generasi, yaitu generasi usia 10-20 tahun, generasi 21-40 tahun, dan generasi 41-60 tahun.

Pada generasi usia 10-20 tahun, sikap bahasa yang banyak digunakan di ranah karib adalah pada skala (4) dan (5) dengan jumlah yang sama, yaitu 97 dari 1000 jawaban (32,33\%). Sakala (4) yaitu lebih sering menggunakan bahasa Indonesia daripada bahasa Cirebon dan skala (5) yaitu selalu menggunakan bahasa Indonesia. Sikap bahasa selanjutnya pada skala (3), (2), dan (1). Skala (3) sama seringnya penggunaan bahasa Cirebon dan bahasa Indonesia dengan jumlah 58 dari 1000 jawaban (19,33\%). Skala (2) lebih sering menggunakan bahasa Cirebon daripada bahasa Indonesia dengan jumlah 21 dari 1000 jawaban (21\%). Skala (1) selalu menggunakan bahasa Cirebon dengan jumlah 20 dari 1000 jawaban $(6,67 \%)$.

Pada generasi usia 21-40 tahun, skala sikap dengan jumlah bahasa terbanyak pada ranah karib secara berturut-turut adalah skala (3), (4), (1), (2), dan skala (5). Skala (3) adalah sama 
Deiksis: Jurnal Pendidikan Bahasa dan Sastra Indonesia, 7 (1) Januari 2020

DOI: $10.33603 /$ deiksis.v7i1.2578

(p-ISSN 2355-6633, e-ISSN 2548-5490) seringnya penggunaan bahasa Cirebon dengan bahasa Indonesia dengan jumlah 197 (39,4\%), skala (4) lebih sering menggunakan bahasa Indonesia daripada bahasa Cirebon dengan jumlah 58 (11,6\%), skala (1) selalu menggunakan bahasa Cirebon dengan jumlah 79 (15,8\%). Skala (2) lebih sering menggunakan bahasa Cirebon daripad bahasa Indonesia dengan jumlah 66 $(13,2 \%)$. Skala paling sedikit jumlahnya yaitu skala (5) selalu menggunakan bahasa Indonesia dengan jumlah $58(11,60 \%)$.

Berbeda dengan generasi sebelumnya, generasi usia 41-60 tahun lebih banyak menggunakan skala (3), (1), (5), (2) dan (4). Skala (3) sama seringnya menggunakan bahasa Cirebon dan bahasa Indonesia dengan jumlah 63(31,5\%). Skala (1) selalu menggunakan bahasa Cirebon dengan jumlah $47(23,5 \%)$. Skala (5) selalu menggunakan bahasa Indonesia dengan jumlah 35 (17,5\%). Skala (2) lebih sering menggunakan bahasa Cirebon daripada bahasa Indonesia dan skala (4) lebih sering menggunakan bahasa Indonesia daripada bahasa Cirebon dengan jumlah 28 (14\%).

Sikap bahasa masyarakat Kota Cirebon pada bahasa Cirebon yang terjadi di ranah karib secara berurutan adalah skala (3), (4), (5), (1), dan skala (2). Skala (3) sama seringnya penggunaan bahasa Cirebon dan bahasa Indonesia dengan jumlah $318(31,8 \%)$. Skala (4) lebih sering menggunakan bahasa Indonesia daripada bahasa Indonesia dengan jumlah $224(22,4 \%)$, skala (5) selalu menggunakan bahasa Indonesia dengan jumlah 190 (19\%). Skala (1) selalu menggunakan bahasa Indonesia dengan jumlah 146 (14,6\%), dan skala yang paling sedikit jumlahnya adalah skala (2) lebih sering menggunakan bahasa Cirebon daripada bahasa Indonesia dengan jumlah 115 (11,5\%).

\section{Ranah Pendidikan}

Pada ranah pendidikan, sikap bahasa masyarakat Kota Cirebon terhadap bahasa Cirebon diejawantahkan dalam tabel berikut.

Tabel 4.1 Sikap Bahasa Masyarakat Kota Cirebon pada Bahasa Cirebon di Ranah pendidikan

\begin{tabular}{|c|c|c|c|c|c|c|c|c|c|c|c|c|}
\hline \multirow{3}{*}{ Ranah } & \multirow{3}{*}{ Usia } & \multirow{3}{*}{$\begin{array}{l}\text { Jml } \\
\text { res- } \\
\text { pon- } \\
\text { den }\end{array}$} & \multicolumn{10}{|c|}{ Jumlah Perolehan Sikap Bahasa Dalam Jumlah Dan Persentase } \\
\hline & & & \multicolumn{2}{|c|}{$\begin{array}{c}\text { (1) } \\
\text { selalu BC }\end{array}$} & \multicolumn{2}{|c|}{$\begin{array}{c}(2) \\
\text { lebih sering } \\
\text { BC drpd BI }\end{array}$} & \multicolumn{2}{|c|}{$\begin{array}{c}(3) \\
\text { sama sering } \\
\text { BC dan BI } \\
\end{array}$} & \multicolumn{2}{|c|}{$\begin{array}{c}(4) \\
\text { lebih sering BI } \\
\text { drpd BC }\end{array}$} & \multicolumn{2}{|c|}{$\begin{array}{c}\text { (5) } \\
\text { selalu BI }\end{array}$} \\
\hline & & & $\underset{\text { jwban }}{\text { Jml }}$ & $\begin{array}{c}\text { Per- } \\
\text { sen }\end{array}$ & $\begin{array}{c}\text { Jml } \\
\text { jwba } \\
\text { n } \\
\end{array}$ & $\begin{array}{c}\text { Per- } \\
\text { sen }\end{array}$ & $\begin{array}{c}\text { Jml } \\
\text { jwban }\end{array}$ & $\begin{array}{c}\text { Perse } \\
\text { n }\end{array}$ & $\begin{array}{c}\text { Jml } \\
\text { jwba } \\
\text { n }\end{array}$ & $\begin{array}{l}\text { Per- } \\
\text { sen }\end{array}$ & $\begin{array}{c}\text { Jml } \\
\text { jwban }\end{array}$ & $\begin{array}{c}\text { Per- } \\
\text { sen }\end{array}$ \\
\hline \multirow{4}{*}{$\begin{array}{l}\text { pendidikan } \\
\text { (10 } \\
\text { pertanyaan) }\end{array}$} & $10-20$ th & 30 & 12 & 4.00 & 3 & 1.00 & 24 & 8.00 & 97 & 32.33 & 157 & 52.33 \\
\hline & $21-40$ th & 50 & 12 & 2.40 & 10 & 2.00 & 81 & 16.20 & 180 & 36.00 & 192 & 38.40 \\
\hline & $41-60$ th & 20 & 3 & 1.50 & 17 & 8.50 & 25 & 12.50 & 54 & 27.00 & 98 & 49.00 \\
\hline & $\mathrm{jml}$ & 100 & 27 & 2.7 & 30 & 3 & 130 & 13 & 331 & 33.1 & 447 & 44.7 \\
\hline
\end{tabular}

Sikap bahasa pada generasi usia 10-20 tahun secara berurutan adalah di skala (5), (4), (3), (1), (2). Skala (5) yaitu selalu menggunakan bahasa Indonesia dengan jumlah 157 (52,33\%). Skala (4) lebih sering menggunakan bahasa Indonesia daripada bahasa Cirebon dengan jumlah 97 (32,33\%). Skala (3) sama seringnya penggunaan bahasa Cirebon dan bahasa Indonesia dengan jumlah 24 (8\%). Skala (1) selalu menggunakan bahasa Cirebon dengan jumlah 12 (4\%), 
Deiksis: Jurnal Pendidikan Bahasa dan Sastra Indonesia, 7 (1) Januari 2020

DOI: $10.33603 /$ deiksis.v7i1.2578

(p-ISSN 2355-6633, e-ISSN 2548-5490)

dan skala paling sedikit adalah skala (2) yaitu lebih sering menggunakan bahasa Cirebon daripada bahasa Indonesia dengan jumlah $3(1 \%)$.

Sikap bahasa pada generasi usia 21-40 tahun secara berurutan adalah di skala (5), (4), (3), (1), dan (2). Skala (5) yaitu selalu menggunakan bahasa Indonesia dengan jumlah 192 $(38,4 \%)$. Skala (4) lebih sering menggunakan bahasa Indonesia daripada bahasa Cirebon dengan jumlah 180 (36\%). Skala (3) sama seringnya penggunaan bahasa Cirebon dan bahasa Indonesia dengan jumlah $81(16,2 \%)$. Skala (1) selalu menggunakan bahasa Cirebon dengan jumlah $12(2,40 \%)$. Skala paling sedikit jumlahnya adalah skala (2) lebih sering menggunakan bahasa Cirebon daripada bahasa Indonesia dengan jumlah 10 (2\%).

Sikap bahasa pada generasi usia 41-60 tahun secara berurutan adalah di skala (5), (4), (3), (2), (1). Skala (5) selalu menggunakan bahasa Indonesia dengan jumlah 98 (49\%). Skala (4) lebih sering menggunakan bahasa Indonesia daripada bahasa Cirebon dengan jumlah 54 (27\%). Skala (3) sama seringnya penggunaan bahasa Cirebon dan bahasa Indonesia dengan jumlah $25(12,5 \%)$. Skala (2) lebih sering menggunakan bahasa Cirebon daripada bahasa Indonesia dengan jumlah 17 (8,5\%). Skala terakhir adalah skala (1) selalu menggunakan bahasa Cirebon dengan jumlah $3(1,5 \%)$.

Sikap bahasa keseluruhan masyarakat Kota Cirebon terhadap bahasa Cirebon di ranah pendidikan secara berurutan adalah di skala (5), (4), (3), (2), dan (1). Sikap bahasa pada skala (5) selalu menggunakan bahasa Indonesia dengan jumlah 447 (44,7\%). Skala (4) lebih sering menggunakan bahasa Indonesia daripada bahasa Cirebon dengan jumlah 331 (33,1\%). Skala (3) sama seringnya penggunaan bahasa Cirebon dengan bahasa Indonesia dengan jumlah 130 (13\%). Skala (2) yaitu lebih sering menggunakan bahasa Cirebon daripada bahasa Indonesia dengan jumlah 30 (3\%). Skala paling sedikit jumlahnya yaitu skala (1) selalu menggunakan bahasa Cirebon dengan jumlah 27 (2,7\%).

5. Ranah Pemerintah

Sikap bahasa masyarakat Kota Cirebon di ranah pemerintah dijabarkan melalui tabel dan deskripsi berikut.

Tabel 5.1 Sikap Bahasa Masyarakat Kota Cirebon pada Bahasa Cirebon di Ranah Pemerintah

\begin{tabular}{|c|c|c|c|c|c|c|c|c|c|c|c|c|}
\hline \multirow{3}{*}{ Ranah } & \multirow{3}{*}{ Usia } & \multirow{3}{*}{$\begin{array}{l}\text { Jml } \\
\text { res- } \\
\text { pon- } \\
\text { den }\end{array}$} & \multicolumn{10}{|c|}{ Jumlah Perolehan Sikap Bahasa dalam Jumlah dan Persentase } \\
\hline & & & \multicolumn{2}{|c|}{$\begin{array}{c}\text { (1) } \\
\text { selalu BC }\end{array}$} & \multicolumn{2}{|c|}{$\begin{array}{c}\text { (2) } \\
\text { lebih sering } \\
\text { BC drpd BI }\end{array}$} & \multicolumn{2}{|c|}{$\begin{array}{c}\text { (3) } \\
\text { sama sering } \\
B C \text { dan } B \mathbf{I}\end{array}$} & \multicolumn{2}{|c|}{$\begin{array}{c}(4) \\
\text { lebih sering BI } \\
\text { drpd BC }\end{array}$} & \multicolumn{2}{|c|}{$\begin{array}{c}\text { (5) } \\
\text { selalu BI }\end{array}$} \\
\hline & & & $\underset{\text { jwban }}{\text { Jml }}$ & $\begin{array}{c}\text { Per- } \\
\text { sen }\end{array}$ & $\begin{array}{c}\text { Jml } \\
\text { jwba } \\
\text { n }\end{array}$ & $\begin{array}{c}\text { Per- } \\
\text { sen }\end{array}$ & $\underset{\text { jwban }}{\text { Jml }}$ & $\begin{array}{c}\text { Perse } \\
\text { n }\end{array}$ & $\begin{array}{c}\text { Jml } \\
\text { jwba } \\
\mathbf{n}\end{array}$ & $\begin{array}{c}\text { Per- } \\
\text { sen }\end{array}$ & $\underset{\text { jwban }}{\text { Jml }}$ & $\begin{array}{l}\text { Per- } \\
\text { sen }\end{array}$ \\
\hline \multirow{4}{*}{$\begin{array}{l}\text { pemerintah } \\
\text { (8 pertanyaan) }\end{array}$} & $10-20$ th & 30 & 5 & 2.08 & 3 & 1.25 & 8 & 3.33 & 39 & 16.25 & 64 & 26.67 \\
\hline & $21-40$ th & 50 & 20 & 5 & 17 & 3.40 & 46 & 11.5 & 150 & 37.5 & 153 & 38.25 \\
\hline & $41-60$ th & 20 & 11 & 6.88 & 14 & 8.75 & 17 & 10.63 & 60 & 37.5 & 51 & 31.88 \\
\hline & $\mathrm{jml}$ & 100 & 36 & 4.5 & 34 & 4.25 & 71 & 8.88 & 249 & 31.13 & 268 & 33.5 \\
\hline
\end{tabular}

Perilaku bahasa yang ditunjukkan masyarakat Kota Cirebon melalui jawaban kuesioner menunjukkan sikap bahasa masyarakatnya. Sikap bahasa tersebut dikelompokkan menjadi tiga generasi usia, yaitu usia 10-20 tahun, 21-40 tahun, dan 41-60 tahun. 
Deiksis: Jurnal Pendidikan Bahasa dan Sastra Indonesia, 7 (1) Januari 2020

DOI: $10.33603 /$ deiksis.v7i1.2578

(p-ISSN 2355-6633, e-ISSN 2548-5490)

Generasi usia 10-20 tahun secara berurutan menunjukkan sikap bahasa di ranah pemerintah pada skala (5), (4), (3), (1), dan (2). Skala (5) menunjukkan sikap selalu menggunakan bahasa Indonesia dengan jumlah 64 dari 240 (26,67\%). Skala (4) menunjukkan sikap lebih sering menggunakan bahasa Indonesia daripada bahasa Cirebon dengan jumlah 39 (16,25\%). Skala (3) sama seringnya penggunaan bahasa Cirebon dan bahasa Indonesia dengan jumlah 8 (3,33\%). Skala (1) selalu menggunakan bahasa Cirebon dengan jumlah 5 (2,08\%), dan skala (2) lebih sering menggunakan bahasa Cirebon daripada bahasa Indonesia dengan jumlah $3(1,25 \%)$.

Generasi usia 21-40 tahun secara berturut-turut menggunakan bahasa yang terbilang melalui skala (5), (4), (3), (1), dan (2). Skala (5) selalu menggunakan bahasa Indonesia dengan jumlah 153 dari 400 jawaban $(38,25 \%)$. Skala (4) lebih sering menggunakan bahasa Indonesia daripada bahasa Cirebon dengan jumlah 150 (37,5\%). Skala (3) sama seringnya penggunaan bahasa Cirebon dan Indonesia dengan jumlah 46 (11,5\%). Skala (1) selalu menggunakana bahasa Cirebon dengan jumlah 20 (5\%), dan skala terakhir yaitu skala (2) lebih sering menggunakan bahasa Cirebon daripada bahasa Indonesia dengan jumlah 17 (3,4\%).

Generasi usia 41-60 memiliki penggunaan bahasa secara berturut-turut pada skala (4), (5), (3), (2), (1). Skala (4) lebih sering menggunakan bahasa Indonesia daripada bahasa Cirebon dengan jumlah 60 dari 160 jawaban (37,5\%). Skala (5) selalu menggunakan bahasa Indonesia dengan jumlah 51(31,88\%). Skala (3) sama seringnya penggunaan bahasa Cirebon dan bahasa Indonesia dengan jumlah 17 (10,63\%). Skala (2) lebih sering menggunakan bahasa Cirebon daripada bahasa Indonesia dengan jumlah 14 (8,75\%). Skala (1) selalu menggunakan bahasa Cirebon dengan jumlah $11(8,75 \%)$.

Berdasarkan deskripsi tiga generasi sebelumnya, maka penggunaan bahasa masyarakat Kota Cirebon pada bahasa Cirebon di ranah pemerintah secara berurutan yaitu di skala (5), (4), (3), (1), dan (2). Skala (5) selalu menggunakan bahasa Indonesaia dengan jumlah 268 dari 2000 jawaban (33,5\%). Skala (4) lebih sering menggunakan bahasa Indonesia daripada bahasa Cirebon dengan jumlah 249 (31,13\%). Skala (3) sama seringnya penggunaan bahasa Cirebon dan bahasa Indonesia dengan jumlah $71(8,88 \%)$. Skala (1) selalu menggunakan bahasa Indonesia dengan jumlah 36 (4,5\%), dan skala (2) lebih sering menggunakan bahasa Cirebon daripada bahasa Indonesia dengan jumlah 34 (4,25\%).

\section{Ranah Umum}

Sikap bahasa masyarakat Kota Cirebon terhadap bahasa Cirebon di ranah umum adalah sebagai berikut.

Tabel 6.1 Sikap Bahasa Masyarakat Kota Cirebon pada Bahasa Cirebon di Ranah Umum

\begin{tabular}{|c|c|c|c|c|c|c|c|c|c|c|c|c|}
\hline \multirow{3}{*}{ Ranah } & \multirow{3}{*}{ Usia } & \multirow{3}{*}{$\begin{array}{l}\text { Jml } \\
\text { res- } \\
\text { pon- } \\
\text { den }\end{array}$} & \multicolumn{10}{|c|}{ Jumlah Perolehan Sikap Bahasa dalam Jumlah dan Persentase } \\
\hline & & & \multicolumn{2}{|c|}{$\begin{array}{c}\text { (1) } \\
\text { selalu BC }\end{array}$} & \multicolumn{2}{|c|}{$\begin{array}{l}\text { (2) } \\
\text { lebih sering } \\
\text { BC drpd BI }\end{array}$} & \multicolumn{2}{|c|}{$\begin{array}{c}(3) \\
\text { sama sering } \\
\text { BC dan BI }\end{array}$} & \multicolumn{2}{|c|}{$\begin{array}{c}\text { (4) } \\
\text { lebih sering BI } \\
\text { drpd BC }\end{array}$} & \multicolumn{2}{|c|}{$\begin{array}{c}(5) \\
\text { selalu BI }\end{array}$} \\
\hline & & & $\begin{array}{c}\text { Jml } \\
\text { jwban }\end{array}$ & $\begin{array}{c}\text { Per- } \\
\text { sen }\end{array}$ & $\begin{array}{c}\text { Jml } \\
\text { jwba } \\
\mathbf{n} \\
\end{array}$ & $\begin{array}{l}\text { Per- } \\
\text { sen }\end{array}$ & $\begin{array}{c}\text { Jml } \\
\text { jwban }\end{array}$ & $\begin{array}{c}\text { Perse } \\
\text { n }\end{array}$ & $\begin{array}{c}\text { Jml } \\
\text { jwba } \\
\mathbf{n} \\
\end{array}$ & $\begin{array}{l}\text { Per- } \\
\text { sen }\end{array}$ & $\begin{array}{c}\text { Jml } \\
\text { jwban }\end{array}$ & $\begin{array}{c}\text { Per- } \\
\text { sen }\end{array}$ \\
\hline umum & $10-20$ th & 30 & 9 & 1.76 & 13 & 2.55 & 33 & 6.47 & 115 & 22.55 & 232 & 45.49 \\
\hline
\end{tabular}


Deiksis: Jurnal Pendidikan Bahasa dan Sastra Indonesia, 7 (1) Januari 2020

DOI: $10.33603 /$ deiksis.v7i1.2578

\begin{tabular}{|l|l|l|l|l|l|l|l|l|l|l|l|l|}
\hline $\begin{array}{l}(17 \\
\text { pertanyaan) }\end{array}$ & $21-40$ th & 50 & 63 & 7.41 & 38 & 4.47 & 121 & 14.24 & 289 & 34.00 & 318 & 37.41 \\
\cline { 2 - 12 } & $41-60$ th & 20 & 25 & 7.35 & 28 & 8.24 & 44 & 12.94 & 110 & 32.35 & 120 & 35.29 \\
\cline { 2 - 13 } & jml & 100 & 97 & 5.71 & 79 & 4.65 & 198 & 11.6 & 514 & 30.24 & 670 & 39.41 \\
\hline
\end{tabular}

Pada tabel 6.1 di atas, penggunaan bahasa masyarakat Kota Cirebon pada bahasa Cirebon di ranah umum dikelompokkan dalam tiga generasi, yaitu generasi usia 10-20 tahun, usia 21-40 tahun, dan usia 41-60 tahun.

Pada generasi usia 10-20 tahun, penggunaan bahasa masyarakat Kota Cirebon pada bahasa Cirebon di ranah umum secara berurutan adalah di skala (5), (4), (3), (2), dan (1). Pada skala (5) selalu menggunakan bahasa Indonesia dengan jumlah 232 dari 510 jawaban $(45,49 \%)$. Skala (4) lebih sering menggunakan bahasa Indonesia daripada bahasa Cirebon dengan jumlah $11(22,55 \%)$. Skala (3) sama seringnya penggunaan bahasa Cirebon dan bahasa Indonesia dengan jumlah $33(6,47 \%)$. Skala (2) lebih sering menggunakan bahasa Cirebon daripada bahasa Indonesia dengan jumlah 13 (2,55\%), dan skala (1) selalu menggunakan bahasa Cirebon dengan jumlah $9(1,76 \%)$.

Pada generasi usia 21-40 tahun, penggunaan bahasa masyarakat Kota Cirebon pada bahasa Cirebon di ranah umum secara berturut-turut adalah skala (5), (4), (3), (1), dan (2). Skala (5) selalu menggunakan bahasa Indonesia dengan jumlah 318 (37,41\%). Skala (4) lebih sering menggunakan bahasa Indonesia daripada bahasa Cirebon dengan jumlah 289 (34\%). Skala (3) sama seringnya penggunaan bahasa Cirebon dan bahasa Indonesia dengan jumlah 121 (14,24\%). Skala (1) selalu menggunakan bahasa Cirebon dengan jumlah 63 (7,41\%). Skala (2) lebih sering menggunakan bahasa Cirebon daripada bahasa Indonesia dengan jumlah 38 $(4,47 \%)$.

Pada generasi usia 41-60 tahun, penggunaan bahasa masyarakat Kota Cirebon pada bahasa Cirebon adalah di skala (5), (4), (3), (2), dan (1). Skala (5) selalu menggunakan bahasa Indonesia dengan jumlah 120 (35,29\%). Skala (4) lebih sering menggunakan bahasa Indonesia daripada bahasa Cirebon dengan jumlah 110 (32,3\%). Skala (3) sama seringnya penggunaan bahasa Cirebon dan bahasa Indonesia dengan jumlah 44 (12,94\%). Skala (2) lebih sering menggunakan bahasa Cirebon daripada bahasa Indonesia dengan jumlah 28 (8,24\%). Skala (1) selalu menggunakan bahasa Cirebon dengan jumlah 25 (7,35\%).

Sikap bahasa masyarakat Kota Cirebon pada bahasa Cirebon di ranah umum secara keseluruhan adalah di skala (5), (4), (3), (1), dan (2). Skala (5) selalu menggunakan bahasa Indonesia dengan jumlah 670 dari 1700 jawaban (670\%). Skala (4) lebih sering menggunakan bahasa Indonesia daripada bahasa Cirebon dengan jumlah 514 (30,24\%). Skala (3) sama seringnya penggunaan bahasa Cirebon dan bahasa Indonesia dengan jumlah $198(11,6 \%)$. Skala (1) selalu menggunakan bahasa Cirebon dengan jumlah 97 (5,71\%). Skala yang paling sedikit jumlahnya adalah skala (2) yaitu lebih sering menggunakan bahasa Cirebon daripada bahasa Indonesia dengan jumlah 25 (7,35\%).

\section{Ranah Agama}

Sikap bahasa masyarakat Kota Cirebon pada bahasa Cirebon di ranah agama adalah sebagai berikut.

Tabel 7.1 Sikap Bahasa Masyarakat Kota Cirebon pada Bahasa Cirebon di Ranah Agama 
Deiksis: Jurnal Pendidikan Bahasa dan Sastra Indonesia, 7 (1) Januari 2020

DOI: $10.33603 /$ deiksis.v7i1.2578

(p-ISSN 2355-6633, e-ISSN 2548-5490)

\begin{tabular}{|c|c|c|c|c|c|c|c|c|c|c|c|c|}
\hline \multirow{3}{*}{ Ranah } & \multirow{3}{*}{ Usia } & \multirow{3}{*}{$\begin{array}{l}\text { Jml } \\
\text { res- } \\
\text { pon- } \\
\text { den }\end{array}$} & \multicolumn{10}{|c|}{ Jumlah Perolehan Sikap Bahasa dalam Jumlah dan Persentase } \\
\hline & & & \multicolumn{2}{|c|}{$\begin{array}{c}(1) \\
\text { selalu BC }\end{array}$} & \multicolumn{2}{|c|}{$\begin{array}{l}(2) \\
\text { lebih sering } \\
\text { BC drpd BI }\end{array}$} & \multicolumn{2}{|c|}{$\begin{array}{c}(3) \\
\text { sama sering } \\
\text { BC dan BI }\end{array}$} & \multicolumn{2}{|c|}{$\begin{array}{c}\text { (4) } \\
\text { lebih sering BI } \\
\text { drpd BC }\end{array}$} & \multicolumn{2}{|c|}{$\begin{array}{c}\text { (5) } \\
\text { selalu BI }\end{array}$} \\
\hline & & & $\begin{array}{c}\text { Jml } \\
\text { jwban }\end{array}$ & $\begin{array}{c}\text { Per- } \\
\text { sen }\end{array}$ & $\begin{array}{c}\text { Jml } \\
\text { jwba } \\
\mathbf{n} \\
\end{array}$ & $\begin{array}{c}\text { Per- } \\
\text { sen }\end{array}$ & $\begin{array}{c}\text { Jml } \\
\text { jwban }\end{array}$ & $\begin{array}{c}\text { Perse } \\
\mathbf{n} \\
\end{array}$ & $\begin{array}{c}\text { Jml } \\
\text { jwba } \\
\mathbf{n} \\
\end{array}$ & $\begin{array}{c}\text { Per- } \\
\text { sen }\end{array}$ & $\begin{array}{c}\text { Jml } \\
\text { jwban }\end{array}$ & $\begin{array}{c}\text { Per- } \\
\text { sen }\end{array}$ \\
\hline \multirow{4}{*}{$\begin{array}{l}\text { agama } \\
\text { (6 pertanyaan) }\end{array}$} & $10-20$ th & 30 & 3 & 1.67 & 3 & 1.67 & 18 & 10.00 & 52 & 28.89 & 79 & 43.89 \\
\hline & $21-40$ th & 50 & 23 & 7.67 & 17 & 5.67 & 122 & 40.67 & 65 & 21.67 & 69 & 23.00 \\
\hline & $41-60$ th & 20 & 13 & 10.83 & 6 & 5.00 & 41 & 34.17 & 16 & 13.33 & 39 & 32.50 \\
\hline & jml & 100 & 39 & 6.5 & 26 & 4.33 & 181 & 30.2 & 133 & 22.17 & 187 & $\begin{array}{l}31.16 \\
7\end{array}$ \\
\hline
\end{tabular}

Berdasarkan tabel 7.1, generasi yang menjadi narasumber penelitian ini adalah usia 10-20 tahun, usia 21-40 tahun, dan usia 41-60 tahun.

Pada generasi 10-20 tahun, bahasa yang banyak digunakan oleh masyarakat Kota Cirebon secara berurutan adalah di skala (5), (4), (3), (1) dan (2). Skala (5) selalu menggunakan bahasa Indonesia dengan jumlah 79 dari 180 jawaban (43,89\%). Skala (4) lebih sering menggunakan bahasa Indonesia daripada bahasa Cirebon dengan jumlah 52 (28,89\%). Skala (3) sama seringnya penggunaan bahasa Cirebon dan bahasa Indonesia dengan jumlah 18 (10\%). Skala (2) dan (1) sama jumlahnya yaitu 3 (1,67\%).

Generasi usia 21-40 tahun secara berturut-turut menggunakan pemilihan bahasa di skala (3), (5), (4), (1), dan (2). Skala (3) sama seringnya penggunaan bahasa Cirebon dan bahasa Indonesia dengan jumlah 122 dari 300 (40,67\%). Skala (5) selalu menggunakan bahasa Indonesia dengan jumlah 69 (23\%). Skala (4) lebih sering menggunakan bahasa Indonesia daripada bahasa Cirebon dengan jumlah 65 (21,67\%). Skala (1) selalu menggunakan bahasa Cirebon dengan jumlah 13 (10,83\%). Skala (2) lebih sering menggunakan bahasa Cirebon daripada bahasa Indonesia dengan jumlah $6(5 \%)$.

Generasi usia 41-60 tahun secara berturut-turut menggunakan pemilihan bahasa di skala (3), (5), (4), (1), dan (2). Skala (3) sama seringnya penggunaan bahasa Cirebon dan bahasa Indonesia dengan jumlah 41 dari 120 jawaban $(34,17 \%)$. Skala (5) selalu menggunakan bahasa Indonesia dengan jumlah 39 (32,5\%). Skala (4) lebih sering menggunakan bahasa Indonesia daripada bahasa Cirebon dengan jumlah 16(13,33\%). Skala (1) selalu menggunakan bahasa Cirebon dengan jumlah 13 (10,83\%). Skala dengan jumlah paling sedikit yaitu skala (2) lebih sering menggunakan bahasa Cirebon daripada bahasa Indonesia dengan jumlah 6 (5\%).

Berdasarkan tabel 7.1, sikap bahasa keseluruhan masyarakat Kota Cirebon pada bahasa Cirebon di ranah agama secara berturut-turut adalah skala (5), (3), (4), (1), dan (2). Skala (5) selalu menggunakan bahasa Indonesia dengan jumlah 187 dari 600 (187\%). Skala (3) sama seringnya menggunakan bahasa Cirebon dan bahasa Indonesia dengan jumlah 181 (30,2\%). Skala (4) lebih sering menggunakan bahasa Indonesia daripada bahasa Cirebon dengan jumlah 133 (22,17\%). Skala (1) selalu menggunakan bahasa Cirebon dengan jumlah 39 (6,5\%). Skala (2) lebih sering menggunakan bahasa Cirebon daripada bahasa Indonesia dengan jumlah 26 $(4,33 \%)$. 
Deiksis: Jurnal Pendidikan Bahasa dan Sastra Indonesia, 7 (1) Januari 2020

DOI: $10.33603 /$ deiksis.v7i1.2578

(p-ISSN 2355-6633, e-ISSN 2548-5490)

\section{Pembahasan}

Menurut Suwito, apabila di dalam suatu masyarakat dikenal lebih dari satu bahasa, maka pemilihan bahasa mana yang akan digunakan sebagai alat komunikasi umum di dalam masyarakat itu menunjukkan sikap masyarakat terhadap bahasa tersebut. Masyarakat Kota Cirebon merupakan masyarakat yang multietnis dan multilingual. Repertoire bahasa mereka cenderung lebih dari dua bahasa, sehingga terjadinya campur dan alih kode bagi penutur sangat berpeluang. Namun, dengan banyaknya repertoire bahasa yang mereka miliki akan mempengaruhi bahasa daerah mereka atau tidak akan dibuktikan dalam penelitian ini.

Pada ranah keluarga, bahasa yang sering digunakan oleh masyarakat Kota Cirebon adalah percampuran antara bahasa Cirebon dan bahasa Indonesia dengan porsi yang sama. Berdasarkan tabel 1.1 urutan penggunaan bahasa masyarakat Kota Cirebon ada di skala (3), (4), (5), (1), dan (2). Skala (3) berarti sama seringnya menggunakan bahasa Cirebon dan bahasa Indonesia, skala (4) lebih sering menggunakan bahasa Indonesia daripada bahasa Cirebon, skala (5) selalu menggunakan bahasa Indonesia, skala (1) selalu menggunakan bahasa Cirebon, dan skala (2) lebih sering menggunakan bahasa Cirebon daripada bahasa Indonesia. Artinya, masyarakat Kota Cirebon selalu menggunakan campur dan alih kode antara bahasa Cirebon dan bahasa Indonesia.

Lingkungan keluarga digadang-gadang sebagai lingkungan yang paling mendukung untuk melestarikan bahasa daerah karena keluarga adalah lingkungan yang paling sering terjadi interaksi antarpenutur. Interaksi yang bersifat individu, intim, dan pribadi. Sehingga, bahasa pertama (ibu) yang digunakan oleh anggota keluarga adalah bahasa daerah. Akan tetapi, peneliti menemukan data yang berbeda bahwa tiga generasi tidak selalu menggunakan bahasa daerah (Cirebon) di lingkungan keluarga, tetapi menggunakan bahasa bahasa Indonesia. Generasi usia 41-60 tahun, dua bahasa yang digunakan di keluarga adalah di skala (3) percampuran bahasa Cirebon dan bahasa Indonesia dan skala (4) lebih sering menggunakan bahasa Indonesia daripada bahasa Cirebon. Generasi tersebut adalah generasi menjadi orang tua. Mereka lebih memilih menggunakan percampuran bahasa Indonesia dan Cirebon daripada memilih selalu menggunakan bahasa Cirebon di lingkungan keluarga. Hal demikian berdampak pada penggunaan bahasa pada generasi selanjutnya. Terbukti bahwa generasi usia 20-40 tahun menggunakan skala (3) sama seringnya menggunakan bahasa Cirebon dan bahasa Indonesia serta skala (4) lebih sering menggunakan bahasa Indonesia daripada bahasa Cirebon. Hal yang sama akan terus berlanjut dari generasi ke generasi.

Data yang peneliti temukan lagi adalah penggunaan bahasa pada generasi usia 10-20 tahun adalah di skala (5) selalu menggunakan bahasa Indonesia dan skala (4) lebih sering menggunakan bahasa Indonesia daripada bahasa Cirebon.

Jika dibandingkan dengan ciri-ciri sikap bahasa menurut Garvin dan Mathiot, maka dapat ditarik kesimpulan masyarakat Kota Cirebon mempunyai sikap bahasa yang tidak positif dan tidak negatif, tetapi mengalami kemunduran.

Untuk menilai sikap bahasa suatu masyarakat, tidak hanya dari ranah keluarga, tetapi juga ranah tetangga, karib, pendidikan, pemerintah, umum, dan agama. 
Deiksis: Jurnal Pendidikan Bahasa dan Sastra Indonesia, 7 (1) Januari 2020

DOI: $10.33603 /$ deiksis.v7i1.2578

(p-ISSN 2355-6633, e-ISSN 2548-5490)

Pada ranah tetangga, penggunaan bahasa yang paling banyak dipakai masyarakat Kota Cirebon adalah di skala (4) lebih sering menggunakan bahasa Indonesia daripada bahasa Cirebon, serta skala (5) yaitu selalu menggunakan bahasa Indonesia.

Pada ranah karib, penggunaan bahasa yang paling banyak dipakai masyarakat Kota Cirebon adalah di skala (3) sama seringnya antara bahasa Cirebon dan bahasa Indonesia, serta skala (4) lebih sering menggunakan bahasa Indonesia daripada bahasa Cirebon.

Pada ranah pendidikan bisa dipastikan bahwa bahasa Indonesia adalah bahasa yang paling banyak digunakan oleh masyarakat Kota Cirebon, yaitu skala (5) selalu menggunakan bahasa Indonesia dan (4) lebih sering menggunakan bahasa Indonesia daripada bahasa Cirebon.

Ranah pemerintah juga sama dengan ranah pendidikan, yaitu selalu menggunakan bahasa Indonesia, yaitu di skala (5) dan skala (4) lebih sering menggunakan bahasa Indonesia daripada bahasa Cirebon.

Ranah selanjutnya adalah ranah umum, yaitu ranah yang memungkinkan masyarakat bertemu dan bertutur dengan siapa pun. Pada ranah ini, bahasa Indonesia adalah bahasa yang paling dominan digunakan oleh masyarakat Kota Cirebon, yaitu di skala (5), dan skala (4) lebih sering menggunakan bahasa Indonesia daripada bahasa Cirebon.

Ranah terkahir merupakan ranah tempat seseorang berdoa kepada TuhanNya dan tempat berkumpul dengan masyarakat sekitar rumah. Hipotesis peneliti, pada ranah agama, masyarakat Kota Cirebon menggunakan bahasa Cirebon. Hal ini karena ranah agama seperti saat berdoa kepada Tuhan adalah hal yang paling intim dilakukan seorang hamba kepada TuhanNya. Tetapi data yang ditemukan adalah umumnya masyarakat Kota Cirebon selalu menggunakan bahasa Indonesia (skala 5). Skala berikutnya adalah percampuran bahasa Cirebon dengan bahasa Indonesia (skala 3).

\section{Kesimpulan}

Berdasarkan hasil ketujuh ranah yang diteliti, dapat disimpulkan bahwa penggunaan bahasa masyarakat Kota Cirebon di 2 ranah (keluarga dan karib) menggunakan bahasa percampuran antara bahasa Cirebon dan Indonesia (skala 3), 1 ranah (tetangga) lebih sering menggunakan bahasa Indonesia daripada bahasa Cirebon (skala 4), 3 ranah (pendidikan, umum, dan agama) selalu menggunakan bahasa Indonesia (skala 5). Oleh karena itu, hasil dari penelitian ini adalah sikap bahasa masyarakat Kota Cirebon pada bahasa Cirebon mengalami kemunduran, tidak positif tetapi berpengaruh ke negatif. Dengan demikian, perlunya perlakuan khusus dari pihak pemerintah daerah, budayawan, dan masyarakat Kota Cirebon untuk terus menggelorakan dan menggairahkan bahasa Cirebon sebagai bahasa daerah yang telah mandiri.

\section{Ucapan Terima Kasih}

Terimakasih penulis ucapkan pada Allah swt yang telah memberikan hidayah dan keselamatan untuk penulis sehingga penulis bisa menyelesaikan penelitian ini dengan lancar.

Selanjutnya, ucapan terimakasih penulis sampaikan pada segala pihak yang telah membantu baik segi finansial, doa, tenaga, dan pikiran, diantaranya :

1. Ristekdikti yang telah membiayai penelitian ini

2. Rektor Universitas 17 Agustus 1945 dan jajarannya. 
Deiksis: Jurnal Pendidikan Bahasa dan Sastra Indonesia, 7 (1) Januari 2020

DOI: $10.33603 /$ deiksis.v7i1.2578

(p-ISSN 2355-6633, e-ISSN 2548-5490)

3. Ketua LPPM Untag Cirebon yang telah membantu dengan segala kebijakannya.

4. Tim Peneliti dan tim surveyor

\section{Daftar Pustaka}

Anderson, A. E. (1974). "Language Attitudes, Belief, Values : A Study Linguistic Cognitive Framework". Disertation of Georgetown University Washington D.C.

Chaer dan Leonie. A (2010). Sosiolinguistik: perkenalan Awal. Jakarta : PT Rineka Cipta.

Dittmar, N. 1976. Sociolinguistics: A Critical Survey of Theory and Application. London:Edward Arnold Ltd.

Fishman A. J. (1972). The Sociology of Language. Rawly Massachusett : Newbury House.

Ibrahim, Ghufron Ali. 2011. "Linguistik Indonesia". Masyarakat Linguistik Indonesia, ISSN: 0215-484, Februari, halaman 35 - 52 Tahun ke-29, No. 1.

Lambert, W.E. (1976). “A Social Psychology of Bilingualism”. Journal of Social Issues 23:91109.

Nababan. (1993). Sosiolinguistik Suatu Pengntar. Jakarta : PT Gramedia Pustaka Utama.

Suplemen Pikiran Rakyat. 2013. Hasil Kongres II Basa Cerbon : Cerbon bahasa baru yang

Mandiri. https://www.facebook.com/notes/gunung-jati-cirebon/hasil-kongres-ii-basacerbon-cerbon-bahasa-baru-yang-mandiri/10151656401558190/ diunduh tanggal 6 Agustus 2019 pukul 11.05 WIB.

Suwito. (1991). Sosiolinguistik. Departemen Pendidikan dan Kebudayaan Republik Indonesia Uiversitas Sebelas Maret Surakarta.

Ruddyanto. (2009). "Perencanaan Bahasa Bali : Sebuah Kasus Penanganan Bahasa Daerah". Peneroka Hakikat Bahasa. Yogyakarta:Universitas Sanata Dharma.

Wagiati. (2017). "Sikap Berbahasa Para Remaja Berbahasa Sunda di Kabupaten Bandung : Suatu Kajian Sosiolinguistik". Metalingua, Desember, ISSN : 2580-2143, Volume 1 Nomor 2, halaman 213-221.

Weinrich, R. (1968). An Introduction to Sociolinguistics. Oxford: Basil Blackwell Ltd. 